\title{
Urea production by the marine bacteria Delaya venusta and Pseudomonas stutzeri grown in a minimal medium
}

\author{
Mette S. Therkildsen, Mai F. Isaksen, Bente Aa. Lomstein* \\ Department of Microbial Ecology, Institute of Biological Sciences, Aarhus University, Building 540, Ny Munkegade, \\ DK-8000 Aarhus C, Denmark
}

\begin{abstract}
The present experiment showed that the marine bacteria Delaya venusta and Pseudomonas stutzeri produced urea when grown in a minimal medium without an external supply of organic nitrogen. The urea production rate depended on the bacterial state of growth, and the highest urea accumulation rates in the medium were found in the growth deceleration phase and in the beginning of the stationary phase. Urea did not accumulate in $D$. venusta cells, whereas the intracellular accumulation of urea in $P$. stutzeri cells exceeded urea accumulation in the medium during exponential growth. Further, $D$. venusta could, in contrast to $P$ stutzeri, hydrolyse urea. We suggest that intracellular purines and pyrimidines (in particular RNA) were potential sources for the observed urea production.
\end{abstract}

KEY WORDS: Marine bacteria - Urea Production - Turnover Growth phases

Urea is an important organic nitrogen compound in the marine environment (e.g. Remsen 1971, McCarthy et al. 1977, Sörensson \& Sahlsten 1987, Price \& Harrison 1988, Lomstein et al. 1989, Cochlan \& Harrison 1991, Therkildsen \& Lomstein 1994). Urea production has been related to the presence and input of readily degradable organic material (Satoh 1980, Lomstein et al. 1989, Therkildsen \& Lomstein 1994) and the highest concentrations of urea have been found in the sediment surface, which is characterized by a low $\mathrm{C} / \mathrm{N}$ ratio. A low $\mathrm{C} / \mathrm{N}$ ratio has been used as an indicator of high quality organic matter (Blackburn 1986, Lomstein et al. 1989, Therkildsen \& Lomstein 1994). Bacteria can play a significant role in the overall production of urea in marine sediments (Pedersen et al. 1993a, Therkildsen \& Lomstein 1994). Purines and pyrimidines are potential precursors for bacterial urea production (e.g. Vogels \& Van der Drift 1976, Busse et al. 1984, Gott-

-Addressee for correspondence. E-mail: bente@pop.bio.aau.dk schalk 1986, Kaspari \& Busse 1986). A substrate addition experiment with anoxic, defaunated marine sediment showed a considerable urea production, when the sediment was supplemented with adenosine 5'monophosphate (AMP), cytidine 5'-monophosphate (CMP), and 16S ribosomal RNA (Therkildsen et al. 1996). However, bacterial urea production from purines and pyrimidines is even more favourable under oxic conditions (Vogels \& Van der Drift 1976) Bovine serum albumin did not stimulate sediment urea production, which indicated that urea was not an important intermediate in protein degradation (Therkildsen et al. 1996). Culture experiments with Thiosphaera pantotropha showed that the bacteria produced urea during exponential growth when cultured under oxic and anoxic conditions in a minimal medium (Pedersen et al. 1993b).

The present experiment was designed to investigate urea production by the marine bacteria Delaya venusta and Pseudomonas stutzeri grown without any supplements of organic nitrogen under oxic conditions. Urea production was followed during the different growth phases of the cultures. $D$. venusta is an aerobic bacterium belonging to the family Halomonadaceae. The uptake, transport and turnover of urea by $D$. venusta has been studied by Jahns (1992). P. stutzeri is a facultative, aerobic, nonfluorescent, denitrifying pseudomonad commonly encountered in diverse habitats, including marine environments, soil, and sewage (Ward \& Cockcroft 1993).

Methods. Delaya venusta was grown at $30^{\circ} \mathrm{C}$, at $\mathrm{pH} 7.3$, in a minimal medium and under oxic conditions. Pseudomonas stutzeri was grown at $18^{\circ} \mathrm{C}$, at $\mathrm{pH}$ 7.0 , in a similar minimal medium and under oxic conditions. The minimal medium contained the following in $\mathrm{g} \mathrm{l}^{-1}: \mathrm{Na}_{2} \mathrm{HPO}_{4}, 2.44 ; \mathrm{KH}_{2} \mathrm{PO}_{4}, 1.52 ;\left(\mathrm{NH}_{4}\right)_{2} \mathrm{SO}_{4}, 0.5$; $\mathrm{MgSO}_{4} \cdot 7 \mathrm{H}_{2} \mathrm{O}, 0.2 ; \mathrm{CaCl}_{2} \cdot 2 \mathrm{H}_{2} \mathrm{O}, 0.05 ; \mathrm{NaCl}_{2} 29.22$; 
and $5 \mathrm{ml}$ of the trace element solution described in Finster et al. (1992). Glucose was added to a final concentration of $10 \mathrm{mM}$.

Samples were withdrawn from the cultures at regular time intervals to follow the change in the urea concentration in the medium, the total concentration of urea (medium+bacteria) and bacterial density. The concentration of urea in the medium was measured on $0.2 \mu \mathrm{m}$ Nucleopore filtered samples by the diacetylmonoxime method (Mulvenna \& Savidge 1992). The total concentration of urea (medium+bacteria) was measured by addition of the acid reagent from the diacetylmonoxime method directly to unfiltered samples. The diacetylmonoxime-sample mixture was thoroughly mixed and reacted for 10 min before centrifugation at $11000 \times g$ for $10 \mathrm{~min}$. The remaining reagents in the Mulvenna \& Savidge (1992) urea method were added to the supernatant, and the concentration of urea was measured. Bacterial density was measured as optical density on a Milton Roy, Spectronic 601 spectrophotometer at $600 \mathrm{~nm}$. Additional samples were withdrawn from the cultures in the beginning and at the end of the experiment to measure the $\mathrm{NH}_{4}{ }^{+}$concentration. $\mathrm{NH}_{4}{ }^{+}$was measured by the salicylatehypochlorite method (Bower \& Holm-Hansen 1980).

Urea turnover was measured twice in Delaya venusta and Pseudomonas stutzeri cultures by the ${ }^{14} \mathrm{C}$-urea isotope dilution technique (Lund \& Blackburn 1989). Eight subsamples ( $2 \mathrm{ml}$ culture) were collected and transferred to $10 \mathrm{ml}$ sterile glass containers (Exetainer, Labco) in each turnover measurement. Half of the samples were used to follow the change in the concentration of urea during incubation and the remaining samples were injected with ${ }^{14} \mathrm{C}$-urea. The ${ }^{14} \mathrm{C}$-incubation was modified slightly from Lund \& Blackburn (1989): (1) the incubation was performed as a 4 point time course $(\sim 0,1.0,1.5,3.5 \mathrm{~h}) ;(2)$ the activity of the injected $10 \mu \mathrm{l}$ of

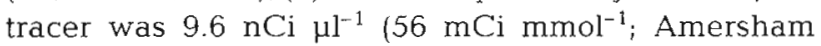
Radiochemical Center); (3) the incubation was terminated by addition of $2 \mathrm{ml} 2.5 \% \mathrm{NaOH}_{\text {; }}$ (4) the scintillation fluid was $\mathrm{pH}$-adjusted OPTIFLUOR ${ }^{\mathrm{TM}}$ from Packard (1:10 v/v 0.1 M NaOH:OPTIFLUOR $\left.{ }^{\mathrm{TM}}\right)$. Urea turnover rates were calculated by the nonsteady-state model I, described in Lund \& Blackburn (1989).

The purity of the Delaya venusta cultures were confirmed microscopically before and after the experiment and during the experiment by the characteristic pea (Pisum sp.) odour of the cultures. Purity of the Pseudomonas stutzeri cultures were confirmed microscopically and by the micromethod API 20 NE for identification of nonenteric Gram-negative rods (bioMérieux) before and after the experiment. $D$. venusta and $P$. stutzeri cultures were purchased from DSM-Deutsche Sammlung von Mikroorganismen und Zellkulturen, Germany.
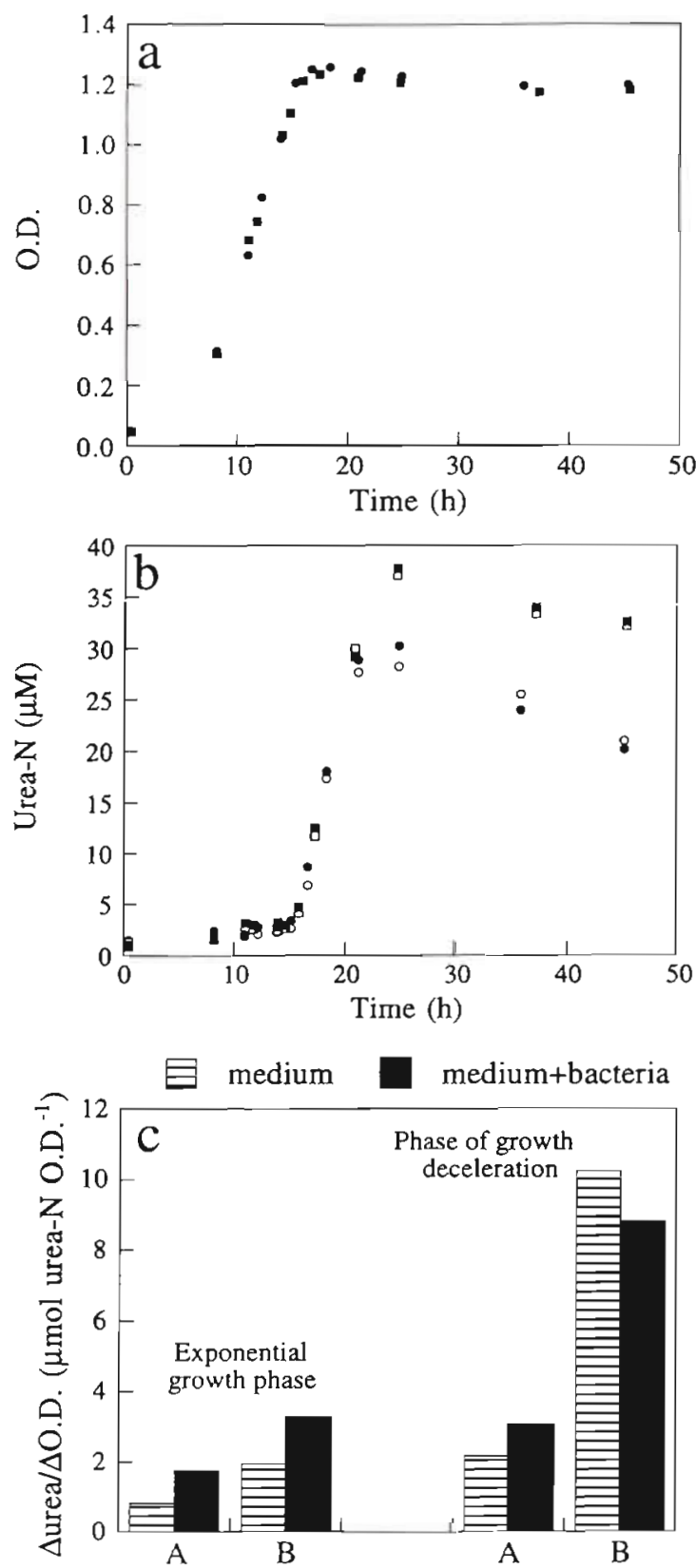

Fig. 1. Delaya venusta. (a) Optical density (O.D.) vs time for 2 cultures. Exponential growth phase: from $t=0.0 \mathrm{~h}$ to $t=$ $12.5 \mathrm{~h}$; growth deceleration phase; from $t=12.5 \mathrm{~h}$ to $t=16.0 \mathrm{~h}$; stationary phase: from $t=16.0 \mathrm{~h}$ to $t=50.0 \mathrm{~h}$. (b) Urea concentrations in medium (open symbols) and medium+bacteria (solid symbols) vs time for 2 cultures. (c) Individual $\Delta$ urea/ $\triangle O D$ rates during exponential growth and in the growth deceleration phase for 2 cultures (A, B)

Results and discussion. Urea production: Delaya venusta and Pseudomonas stutzeri produced urea during the exponential growth phase, in the phase of growth deceleration, and in the stationary phase, when they were grown in a minimal medium under oxic con- 

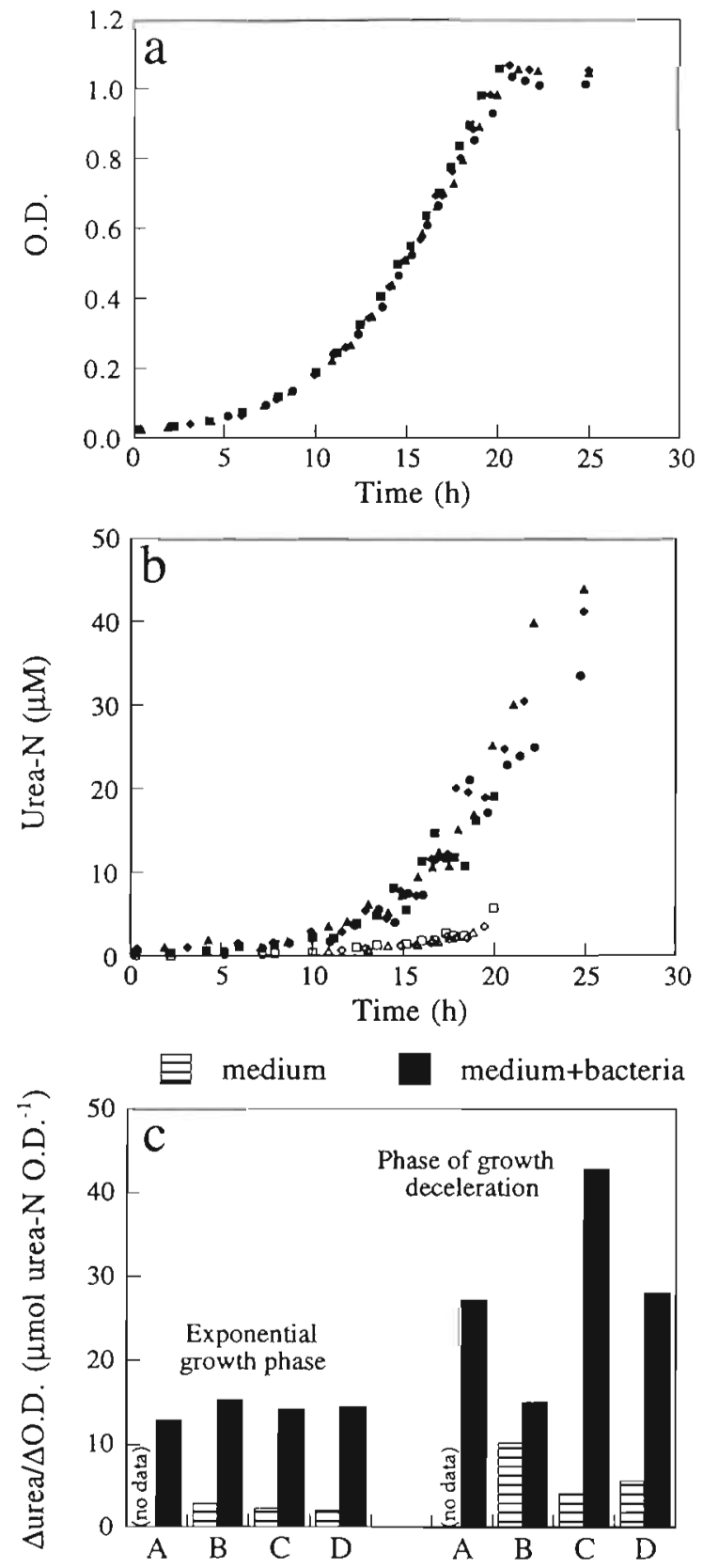

Fig. 2. Pseudomonas stutzeri. (a) Optical density (O.D.) vs time for 4 cultures. Exponential growth phase: from $t=1.0 \mathrm{~h}$ to $t=16.5 \mathrm{~h}$; growth deceleration phase: from $t=16.5 \mathrm{~h}$ to $t=$ $20.0 \mathrm{~h}$; stationary phase: from $t=20.0 \mathrm{~h}$ to $t=30.0 \mathrm{~h}$. (b) Urea concentrations in medium (open symbols) and medium+ bacteria (solid symbols) vs time for 4 cultures. (c) Individual $\triangle$ urea/ $\triangle O D$ rates during exponential growth and in the growth deceleration phase for 4 cultures (A, B, C, D)

ditions (Figs. 1 to 3). The different growth phases were as defined by Buchanan (1918).

The change in optical density (OD), the urea concentration in the medium and the summed medium+bacteria urea concentration with time in 2 Delaya venusta
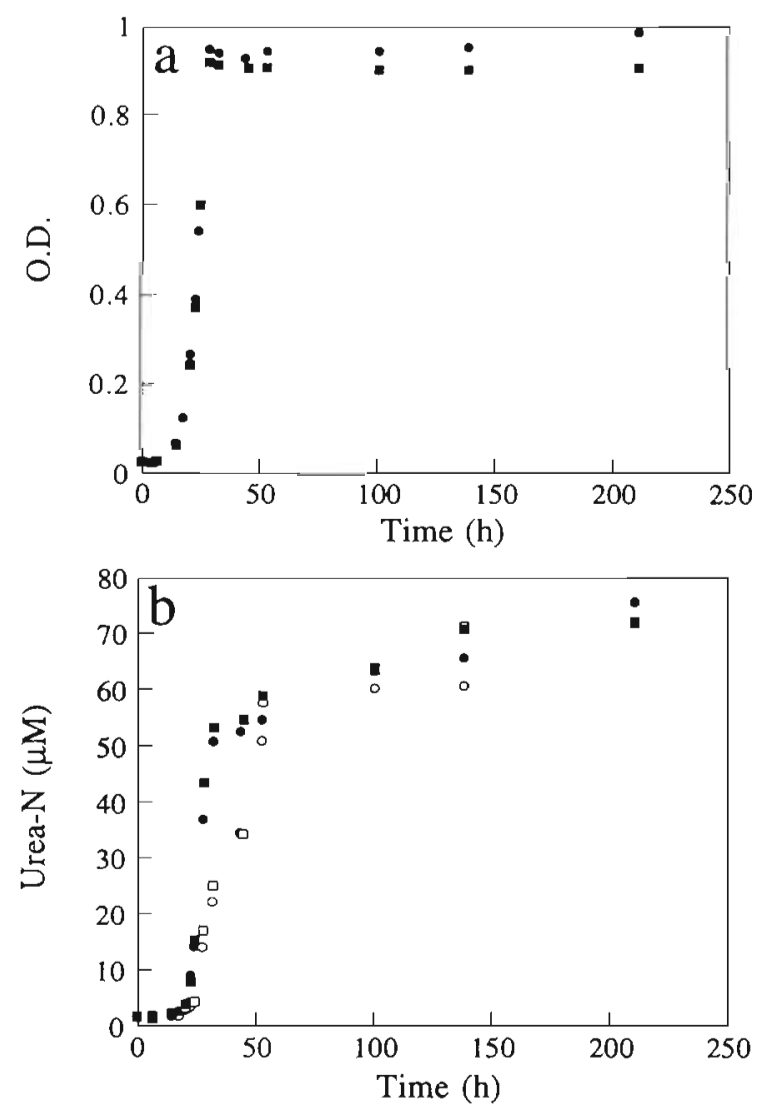

Fig. 3. Pseudomonas stutzeri. (a) Optical density (O.D.) vs time for 2 cultures. Exponential growth phase: from $t=10 \mathrm{~h}$ to $t=25 \mathrm{~h}_{\text {; }}$ growth deceleration phase: from $t=25 \mathrm{~h}$ to $t=27 \mathrm{~h}$; stationary phase: from $t=27 \mathrm{~h}$ to $t=210 \mathrm{~h}$. (b) Urea concentrations in medium (open symbols) and medium+bacteria (solid symbols) vs time for 2 cultures

cultures are shown in Fig. $1 \mathrm{a}$ and $\mathrm{b}$, respectively. The mean generation time was $2.84 \pm 0.01 \mathrm{~h}$. The urea concentration in the medium and medium+bacteria extract were similar, which indicated that there was no urea accumulation within $D$. venusta cells. The increase in the urea concentration in the medium was proportional to bacterial density ( $\triangle$ urea/ $\triangle O D)$ during exponential growth $\left(1.9 \pm 1.0 \mu \mathrm{mol}\right.$ urea-N OD $\left.{ }^{-1}\right)$ and in the subsequent phase of growth deceleration (6.1 \pm $4.0 \mu$ mol urea-N OD $^{-1}$ ). The rates were means of rates from individual cultures. The $\Delta$ urea/ $\triangle O D$ for the individual cultures are shown in Fig. 1c. The increase in urea concentration was also linearly related to time

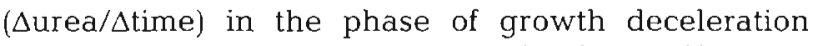
and was $0.7 \pm 0.3 \mu \mathrm{mol}$ urea- $\mathrm{N} \mathrm{I}^{-1} \mathrm{~h}^{-1}$. The ${ }^{14} \mathrm{C}$-urea turnover incubation took place from $t=14.8 \mathrm{~h}$ to $t=$ $18.1 \mathrm{~h}$, and covered the phase of growth deceleration and the beginning of the stationary phase. Urea turnover was $\sim 0.6 \mu \mathrm{mol}$ urea $-\mathrm{N}^{-1} \mathrm{~h}^{-1}$. The highest rate of urea accumulation in the medium was found in the beginning of the stationary phase from $t=16 \mathrm{~h}$ to $t \approx$ 
$22 \mathrm{~h})$, where urea accumulated at a rate of $4.8 \pm 0.3 \mu \mathrm{mol}$ urea- $\mathrm{N}^{-1} \mathrm{~h}^{-1}$, despite bacterial density remaining constant. However, after some time ( $>24 \mathrm{~h}$ ), the urea concentration in the medium declined ( $\Delta$ urea $/ \Delta$ time $=$ $-0.3 \pm 0.1 \mu \mathrm{mol}$ urea $-\mathrm{N} \mathrm{l}^{-1} \mathrm{~h}^{-1}$ ) due to reduced urea production and a substantial urea turnover $(1.8 \mu \mathrm{mol}$ urea$\mathrm{N}^{-1} \mathrm{~h}^{-1}$ from $t=36.0 \mathrm{~h}$ to $t=39.8 \mathrm{~h}$ ). It is likely that $D$. venusta hydrolysed urea during most of the experiment even though $\mathrm{NH}_{4}^{+}$was present in the medium in concentrations $>2 \mathrm{mM}$. Continuous measurements of urea turnover in $D$. venusta cultures, grown under similar conditions, showed that urea turnover took place during all 3 growth phases (authors' unpubl. data). Contrary to these findings, Jahns (1992) found urea uptake by $D$. venusta to be strongly inhibited by an $\mathrm{NH}_{4}{ }^{+}$concentration of $0.1 \mathrm{mM}$.

Four Pseudomonas stutzeri cultures were used to study the exponential and deceleration phases (Fig. 2a, b), while 2 remaining cultures were used to study the stationary phase (Fig. 3a, b). The mean generation time in the $P$. stutzeri cultures was $3.1 \pm 0.1 \mathrm{~h}$. Urea accumulation in the medium and in the medium+bacteria were linearly related to bacterial density during exponential growth. The intracellular accumulation of urea exceeded urea accumulation in the medium. as the urea accumulation rates in the medium and medium+bacteria were $2.4 \pm 0.4(n=3)$ and $14.1 \pm$ $1.0 \mu \mathrm{mol}$ urea-N OD-1 $(\mathrm{n}=4)$, respectively. The $\Delta$ urea/ $\triangle O D$ for the individual cultures are shown in Fig. 2c. A similar difference between the urea accumulation rate in the medium and in the medium +bacteria was found in the growth deceleration phase, where the $\Delta$ urea/ $\triangle \mathrm{OD}$ increased to $6.7 \pm 3.2$ and $28.2 \pm 11.4 \mu \mathrm{mol}$ urea$N O D^{-1}$, respectively. After the bacteria entered the stationary phase ( $t \geq 25 \mathrm{~h}$ ), there was an accumulation of urea in the medium and the $\Delta$ urea/ $\Delta$ time was $\geq 1.5 \mu \mathrm{mol}$ urea- $\mathrm{N}^{-1} \mathrm{~h}^{-1}$ in the medium and $\geq 0.7 \mu \mathrm{mol}$ urea-N $\mathrm{l}^{-1} \mathrm{~h}^{-1}$ in medium+bacteria (Fig. 3b). After $\sim 25 \mathrm{~h}$ in the stationary phase the urea concentration in the medium and in the medium + bacteria were approximately the same, and urea continued to accumulate in the medium at a rate of $0.11 \pm 0.03 \mathrm{~mol}$ urea $-\mathrm{N}^{-1} \mathrm{~h}^{-1}$ during the rest of the experiment (to $t=210 \mathrm{~h}$ ). It is not known why $P$. stutzeri cells accumulated urea during exponential growth and in the phase of growth deceleration. There was no urea turnover in the $P$. stutzeri cultures during any of the growth phases and this result was in agreement with results of the API $20 \mathrm{NE}$ micromethod, which showed that there was no urease activity. Bacteria may have an energetic advantage by excretion of urea compared to $\mathrm{NH}_{4}{ }^{+}$in marine sediments, as the sediment concentration of $\mathrm{NH}_{4}{ }^{+}$often is much higher than the concentration of urea (Rosenfeld 1981, Lomstein et al. 1989). The concentration of $\mathrm{NH}_{4}{ }^{+}$ in natural surface sediments can vary between $<100$ and $10000 \mu \mathrm{M}$ (Blackburn \& Henriksen 1981, Rosenfeld 1981, Lomstein et al. 1989). The $\mathrm{NH}_{4}{ }^{+}$concentration in the medium decreased from $7.56 \mathrm{mM}$ at the beginning of the experiment to $2.32 \mathrm{mM}$ at the end of the experiment.

Potential urea precursors: There is a considerable synthesis and break down of internal RNA during bacterial growth (e.g. Norris \& Koch 1972, Kjelleberg et al. 1987. Mason \& Egli 1993). Some of the RNA is converted to smaller building blocks which is used in the synthesis of new RNA, while part of the RNA is further degraded to urea and $\mathrm{NH}_{4}{ }^{+}$. The mRNA degradation, in particular, is high during exponential growth (e.g. Norris \& Koch 1972) and may have been a potential source for the observed urea production in the present experiments. The degradation of RNA increases immediately after carbon exhaustion (Mason \& Egli 1993) and will ultimately result in a decrease in bacterial RNA content (e.g. Kjelleberg et al. 1987). Accordingly, we found the highest urea production rates in the phase of growth deceleration and when the cultures entered the stationary phase.

Conclusion: The present experiment showed that bacterial urea production can take place without an externally supplied organic nitrogen source and that the urea production rate depended on the bacterial state of growth. We suggest that intracellular purines and pyrimidines, in particular RNA, were potential sources for the observed urea production.

Acknowledgements. We thank Kai Finster for assistance in the laboratory. Financial support was obtained from the Centre for Strategic Environmental Research in Marine Areas, Grant no. 4.15 and from the Danish Natural Science Research Council.

\section{LITERATURE CITED}

Blackburn TH (1986) Microbial processes of N- and C-cycles in marine sediments. In: Megusar F, Ganter $M$ (eds) Perspectives in microbial ecology. Slovene Society for Microbiology, Ljubljana, p 218-224

Blackburn TH, Henriksen K (1983) Nitrogen cycling in different types of sediments from Danish waters. Limnol Oceanogr 28:477-493

Bower CE, Holm-Hansen T (1980) A salicylate-hypochlorite method for determining ammonia in seawater. Can J Fish Aquat Sci 37:794-798

Buchanan RE (1918) Life phases in a bacterial culture. J Infect Dis 23:109-125

Busse W, Kaspari H, Klemme JH (1984) Urea: an interznediate of aerobic and anaerobic purine degradation in Rhodopseudomonas capsulata. FEMS Microbiol Lett 25:33-36

Cochlan WP, Harrison PJ (1991) Uptake of nitrate, ammonium, and urea by nitrogen-starved cultures of Micromonas pusila (Prasinophyceae): transient responses. J Phycol $27: 673-679$

Finster K, Tanimoto X, Bak F (1992) Fermentation of methanethiol and dimethylsulfide by a newly isolated methanogenic bacterium. Arch Microbiol 157:425-430 
Gottschalk G (1986) Bacterial metabolism. Springer-Verlag, New York

Jahns T (1992) Urea uptake by the marine bacterium Delaya venusta HG1. J Gen Microbiol 138:1815-1820

Kaspari H. Busse W (1986) Oxidative degradation of purines by the facultative phototrophic bacterium Rhodopseudomonas capsulata. Arch Microbiol 144:67-70

Kjelleberg S, Hermansson M, Mårdén P (1987) The transient phase between growth and nongrowth of heterotrophic bacteria, with emphasis on the marine environment. Annu Rev Microbiol 41:24-49

Lomstein BAa, Blackburn TH, Henriksen K (1989) Aspects of nitrogen and carbon cycling in the northern Bering Shelf sediment. I. The significance of urea turnover in the mineralization of $\mathrm{NH}_{4}^{+}$. Mar Ecol Prog Ser 57:237-247

Lund BAa, Blackburn TH (1989) Urea turnover in a coastal marine sediment measured by a ${ }^{14} \mathrm{C}$-urea short-term incubation. J Microbiol Methods 9:297-308

Mason CA, Egli T (1993) Dynamics of microbial growth in the decelerating and stationary phase of batch culture. In: Kjelleberg $S$ (ed) Starvation in bacteria. Plenum Press, New York, p 81-102

McCarthy JJ, Taylor WR, Taft JL (1977) Nitrogenous nutrition of the plankton in Chesapeake Bay. 1. Nutrient availability and phytoplankton preferences. Limnol Oceanogr 22: 996-1011

Mulvenna PF, Savidge G (1992) A modified manual method for the determination of urea in seawater using the diacetylmonoxime reagent. Estuar Coast Shelf Sci 34: $429-438$

Norris TE, Koch AL (1972) Effect of growth rate on the relative rates of synthesis of messenger, ribosomal and transfer RNA in Escherichia coli. J Mol Biol 64:633-649

Responsible Subject Editor: Frede Thingstad, Roskilde, Denmark
Pedersen H, Lomstein BAa, Blackburn TH (1993a) Evidence for bacterial urea production in marine sediments. FEMS Microbiol Ecol 12:51-59

Pedersen $\mathrm{H}$, Lomstein BAa, Isaksen MF, Blackburn TH (1993b) Urea production by Thiosphaera pantotropha and by anaerobic enrichment cultures from marine sediments. FEMS Microbiol Ecol 13:31-36

Price NM, Harrison PJ (1988) Uptake of urea C and urea N by the coastal marine diatom Thalassiosira pseudonana. Limnol Oceanogr 33:528-537

Remsen CC (1971) The distribution of urea in coastal and oceanic waters. Limnol Oceanogr 16:732-740

Rosenfeld JK (1981) Nitrogen diagenesis in Long Island Sound sediments. Am J Sci 281:436-462

Satoh Y (1980) Production of urea by bacterial decomposition of organic matter including phytoplankton. Int Rev Ges Hydrobiol 65:295-301

Sörensson F, Sahlsten E (1987) Nitrogen dynamics of a cyanobacteria bloom in the Baltic Sea: new versus regenerated production. Mar Ecol Prog Ser 37:277-284

Therkildsen MS, King GM, Lomstein BAa (1996) Urea production and turnover following the addition of AMP, CMP, RNA and a protein mixture to a marine sediment. Aquat Microb Ecol 10:173-179

Therkildsen MS, Lomstein BAa (1994) Seasonal variation in sediment urea turnover in a shallow estuary. Mar Ecol Prog Ser 109:77-82

Vogels GD, Van der Drift C (1976) Degradation of purines and pyrimidines by microorganisms. Bacteriol Rev 40:403-468

Ward BB, Cockcroft AR (1993) Immunofluorescence detection of the denitrifying strain Pseudomonas stutzeri (ATCC 14405 ) in seawater and intertidal sediment environments. Microb Ecol 25:233-246

Manuscript received: October 3, 1996

Revised version accepted: April 9, 1997 